\title{
Dear LSE: Notes on an Academic Disaster
}

\author{
Hermínio Martins
}

Published online: 21 May 2011

(C) Springer Science+Business Media, LLC 2011

Recently, the UK Government, via its Higher Education "transmission belts", added a new demand to the already hard-driven, cash-strapped British universities: "impact". "Excellence" in research and teaching, quantity and quality of scholarly publications, international recognition, number of top places in the world rankings of universities, Nobel Prizes and the like, where the UK has done exceptionally well, second place only to the US, are all very well. But, in addition, "impact" of all research in universities and publications by academics must be demonstrated when assessments of individual academics, departments, centres, colleges and universities take place, which assessments directly or indirectly count decisively for future funding. The term appears to subsume all publicity outside academia regarding academic work, such as references to it in print and broadcast media (any and all, it seems, not just the quality press or the $\mathrm{BBC}$ ), public interest as evinced by civil society, NGOs, and other associations, and so on....

The most notorious, and unanticipated, example of the public "impact" any university institution has had this year has been the London School of Economics and Political Science, or, simply, the LSE. The imbroglio concerned its varied connections with Libya, not least the donation by Saif al-Islam Gadaffi, a very recent $\mathrm{PhD}$ at the LSE, via his Foundation, of 1.5 million pounds to the Centre for Global Governance at the School, accepted by its governing body, the LSE Council, in 2009, a decision later rescinded in the wake of adverse and strident comments the acceptance provoked in due course in the British media. All this was noted throughout the world, in newspapers and magazines,

H. Martins $(\bowtie)$

35 Cavendish Road,

Oxford OX2 7TN, UK

e-mail: herminio.martins@virgin.net in radio and television stations, by the commentariat, the blogosphere and the videosphere. For a few weeks (FebruaryMarch), the LSE was a world cynosure: this was perhaps the first global university scandal, certainly the first to affect a university institution with the kind of national and especially international reputation and indeed affection the LSE has enjoyed for seven or eight decades (with alumni in government, the civil service, business and universities throughout the English-speaking world, in Europe and Asia), and perhaps the first corporate academic scandal to attract so much worldwide negative publicity over a month or so.

The Director of the School, Sir Howard Davies, with no other blemish on his record as Director, but who had backed the decision to accept the donation when discussed at the LSE Council, felt compelled to resign on March 3, owing to the "reputational damage" (his own words) inflicted on the School by that "error of judgment". No previous Director of the School had resigned under similar circunstances, nor under such a blaze of publicity, nor, I believe, any other head of a British university, or at any rate of any of the top-ranked institutions, over issues of this kind. The resignation of the Director (no one else at LSE has resigned so far, though all members of the Council of the School had concurred in the decision) was followed in the same day by the announcement of an independent inquiry headed by a very distinguished judicial figure, Lord Woolf (former Lord Chief Justice, the highest law officer in the land), charged to scrutinize every aspect of the affair, at the request of the LSE. The request for such an inquiry was itself a rather unusual move in the history of UK universities. The two announcements brought some relief to the besieged LSE, at least in this area, since all British universities are under stress, owing to changing, incoherent, noxious Government policies over funding and other key issues, including academic freedom. 
Disparaging comments on academe and academics are by no means unusual in the UK media: there has been a definite anti-university, anti-social science and indeed, for historic reasons, specifically anti-LSE animus for some decades. But the conduct of the LSE over its Libyan connections provided a prima facie case for severe criticism, and this time it was initially the quality Press which was in the lead, with articles, news items, repeated editorials, and extensive correspondence in London papers such as The Independent, The Guardian and The Times, and their counterparts in other countries, spreading also to the blogospere and audiovisual media. Subsequently, lesser newspapers in Britain lavished their always to be feared attentions on the LSE with such epithets as the "Libyan School of Economics" and "the London School of useful idiots", casting all sorts of aspersions on the academic integrity of the School, and quoting all sorts of unfortunate eulogies of Muammar Gadaffi and his son Saif over the last 6 years or so, by past and present members of its faculty, including the former Director (2002-2008), the worldrenowned sociologist, Anthony Giddens.

Eventually, the Press sought to investigate the Libyan connections of other British universities. It turned out that perhaps 112 of the 130 universities in the UK had, or have had, or had at least at some point contemplated a Libyan connection of some sort, however minor, such as the training of Libyan nurses, engineers, and indeed, more dubiously, police officers. A number of top-ranking universities had been involved, including several in London besides the LSE.

Going further, donations by the Middle Eastern autocracies, or by Middle Eastern billionaires of somewhat unclear pasts, to British universities for the setting up, for example, of Business Schools (the Said Business School attached to Oxford University is a case in point), or programmes of Middle Eastern, Arab or Islamic Studies, or to support museums and art galleries attached to universities, were noticed and questioned. This showed the acute dependency of British universities on kinds of external funding which raise concerns of academic integrity, possibly subtle bias, prudent silences over certain themes or facts, or worse (even historical maps incorporating plain falsehoods, on display in museums which have been the recipients of such gifts, seem immune to scholarly emendation).

Libyan academic connections would always have incurred the most odium by far amongst the autocracies in the Maghreb (Lockerbie alone would account for this), as should have been obvious to the LSE. It is true that the Blair Government convinced itself that it had managed to turn the volatile Colonel away from such things, with Libya ceasing to be a rogue state. Something like a collective Libyan mirage, shared by British business and academia, even members of the Royal Family, in the first instance dreamed up by the Prime Minister, swept the UK.
There were good reasons why the LSE, of all British academic institutions, suffered the most revulsion in the UK against its Libyan connections. A number of occurrences, making up a unique constellation, brought this about. We are going to list the main ones and discuss them seriatim.

- Two articles by Lord Giddens, one in The New Satesman in 2006, one in The Guardian in 2007, based on visits to Libya and interviews with the Brother Leader in Tripoli (the visits were arranged by a Boston-based consultancy, the Monitor Group, which also brought over to meet the Colonel, in addition to Lord Giddens, Profs. Benjamin Barber, Robert Putnam, Joseph Nye, Bernard Lewis and F. Fukuyama, with a view to improving his world image). In these two articles the eminent sociologist gave a picture of Libya as a relatively "benign" one, as repressive regimes go, and stated his belief that the Guide to the Revolution was "genuinely popular", and only he, could lead a peaceful and orderly transition to a more liberal order, giving civil society a substantial voice in the process. Indeed, in a pronouncement which will not be easily forgotten, he ventured to say that Libya under Gaddafi could become the Norway of North Africa, "a prosperous, egalitarian and forward-looking".

Certainly, Libya, a petro-State, was the richest country in North Africa, with reasonable rankings in the Human Development Index, and economic policies praised by the IMF (for what that's worth). But it is difficult to accept that, on the basis of the facts known at the time about current practices in Libya (imprisonment and torture of dissidents, no independent communications media or judiciary), serious social scientists could have believed that, in the end, association with the Libyan regime would not taint them as individuals, and, even worse, their institutions. That some very smart people with LSE connections failed to see this led some critics to recall the deluded works on the USSR by the founders of the School, Sidney and Beatrice Webb, written in the 1930s (long after the founders have had anything more to do with the School). They were representatives of what the sociologist Paul Hollander called "political pilgrims" (in a book with this title), who saw in Communist countries much that was not there, and failed to see the monstrosities taking place (Lincoln Steffens's famous phrase, "I have seen the future and it works" was coined before he arrived in the USSR). A new breed of pofessorial political pilgrims seems to have emerged in the post-communist world if Profs. Giddens, Held, Barber et al. are anything to go by, who see reform and reformers where they don't really exist. A glaring failure by several fine theoretical minds to come to grips with the realities of contemporary despotisms. 
- The admission of Saif al-Islam Gaddafi to LSE in 2002, first to take a one-year MSc course in philosophy and public policy, and after completing this, to do a PhD in international relations completed in 2008. There are two points here: should he have been admitted at all, and did he have appropriate qualifications for entry? Regarding the first, I would argue that the son of a ruling dictator should not have been admitted, however talented and qualified: the child of a dead or deposed dictator, perhaps, or, more convincingly, one who had either severed all political ties with the regime, even if he had not become an overt opponent, or had chosen a totally apolitical career in scholarship. This did not apply to Saif, a man of obvious wealth, influence and political ambition within the framework of his father's dictatorial rule. Secondly, did he have the proper qualifications for admission to LSE as a graduate student? The School claims that he did, but scrutiny by at least one blogger has shown that there are questions to be answered about these claims. They were not, it seems, straightforward qualifications from totally reputable institutions.

- The doubts concerning the authenticity of his $\mathrm{PhD}$ thesis (the text is available online for everyone's scrutiny). This is a matter under investigation, though 17 plagiarized passages had been detected at the time of this writing. There have also been claims that it was written by someone else, but the examiners (or at least the internal examiner, Lord Desai, Emeritus Professor of economics at LSE) claim that the long oral examination they conducted provided no indication of either plagiarism or it having been ghost-written (they did ask for revisions and corrections, which were carried out to their satisfaction). Possibly the work was the result of a team effort, as forensic linguistics may show (many PhDs by foreign students in Britain have been written in a language other than English and translated by somebody else). More light could have been thrown on this question if the extent of his supervision during his years at LSE had been disclosed, but almost nothing is known about this outside the School (Prof. Held was only an informal mentor, even if obviously a crucial one; Prof. Nancy Cartwright, an eminent philosopher of science, was his supervisor of record). The matter may never be fully cleared up. Incidentally, it would have been more appropriate in this instance to have had two external examiners for the thesis, to minimize future criticism (this happens in exceptional cases, and there were odd features about this case).

- The agreement by Oxford University Press to publish a revised version of Saif's LSE PhD thesis, on the grounds of academic merit, presumably owing to the recommendations of two or three academics at least (presumably at least one of them was from the LSE). It is not easy to publish pedestrian scholarly books under this imprint, so the recommendations must have been strong. It has been claimed that Saif wrote two further books, characterized by Prof. Benjamin Barber as "extraordinary", and by a Libya expert at Dartmouth College as "execrable". I have not had access to them.

- The choice of Saif to give the Miliband Memorial Lecture for 2010 by Prof. David Held was startling, a special honour to a very recent graduate, and singularly inappropriate for a lecture instituted to honour a significant, and widely read, Marxist scholar in political studies, who lectured at LSE for a number of years. Ralph Miliband was the father of Ed Miliband, the leader of the Labour Party, and of David Miliband, former Foreign Secretary and defeated candidate for that leadership, who described the choice recently in a TV interview as "horrid". Prof. Held is supposed to be ghost-writing a big-ideas book for the leader of the Labour Party.

- The presentation by Prof David Held at the opening of this lecture . In his panegyric he spoke of Saif as "someone who looks to democracy, civil society and deep liberal values as the core of his inspiration", words which presumably will haunt him for the rest of his life. Prof. Held could have tutored Saif privately on whatever democracy model he favoured, but he should not have put the good name of the School at risk by making such preposterous statements in public at a formal occasion at LSE (he had opportunities for talking to Saif outside the LSE and indeed he visited Tripoli just before the uprising started in Libya).

- Accepting a donation by the Qaddafi Foundation (the Gaddafi International Charity and Development Foundation) so shortly after the $\mathrm{PhD}$ thesis of Saif had been examined, was itself badly timed, for it was to be expected that suspicions would arise. But in any case the acceptance itself was surprising, given that Prof. Fred Halliday, certainly the most knowledgeable person at LSE about Libya at that time, and an Arabic speaker, unlike Prof. Held, had presented a memorandum arguing the case against the acceptance of the gift (the memorandum is available online). One of the arguments of Prof. Held, whose Center for Global Governance would be the beneficiary, it has been alleged, was that rejection of the gift would be "embarrassing" for the son of the dictator. The fact that no-one at the LSE Council heeded Prof. Halliday's warnings about the character of the regime as a corrupt kleptocracy, not undergoing genuine reform, to vote against, is disturbing. Even S. Chakrabarty, a vocal director of Liberty (roughly the equivalent of the ACLU in the US), someone whom one would expect to take a firm stand 
for human rights at all times, went along with the decision. To compound matters, Held was a member of the Board of the Foundation, but even the LSE Council could not stomach this, and he had to resign from it.

It has been argued by Prof. Richard Sennett, recently retired from LSE, and other academics, that UK universities, lacking large endowments, with much reduced funding from the State, and bereft of philanthropic donations from within the country, may be forced to accept donations from unsavoury regimes. It is true that UK universities have been sentenced to a treadmill of perpetual mendicancy. But some British university institutions, in dire financial straits, have rejected tempting donations from autocracies. The LSE was not facing such a plight: on the contrary, according to the outgoing Director, its financial situation was very reasonable.

- A video-conference with Gaddafi held at LSE, at which the LSE lecturer conducting it presented the Brother Leader with an LSE cap, the first person to be so honoured having been Nelson Mandela. The LSE has taken note of the criticism levelled at this lapse of elementary moral decency: it has now discontinued the practice of such presentations, no matter how distinguished or saintly the invited speakers at the LSE may be.
- The fact that the Director of the School had been acting as a financial adviser to the Libyan sovereign wealth fund, apparently at the urging of the UK Government. In itself it was a very minor matter, but under the circumstances, it did not help the LSE.

These have been sorry days for the LSE, and for all those throughout the world with an emotional attachment to the School. Let us hope the institution really does learn from the disaster and undergoes substantial and honest self-examination (deleting the word "Libya" from its website is not what this means), which may call for changes in its own governance. It will, of course, have top take into account the critical report on what happened to bring it about which will be presented by Lord Woolf in due course, though surely the LSE should have been able to work out for itself what ethical guidelines it should follow in future.

Hermínio Martins is Emeritus Fellow, St. Antony's College, University of Oxford and Honorary Research Fellow, Institute of Social Sciences, University of Lisbon. His most recent book is Experimentum humanum: Technological Civilization and the Human Condition (in Portuguese). 